\title{
A Comparative Study of Three English Translations of Yasin Surah Regarding Vinay and Darbelnet Strategies
}

\author{
Mojtaba Aghajani ${ }^{1, *} \&$ Goldis Seyedi Jalali ${ }^{2}$ \\ ${ }^{1}$ Khatam Ol-Anbia University, Tehran, Iran \\ ${ }^{2}$ Rudaki Institute of Higher Education, Tonekabon, Mazandaran, Iran \\ *Correspondence: Khatam Ol-Anbia University, Tehran, Iran. Tel: 98-911-117-8110 E-mail: \\ mojtaba_aghajani45@yahoo.com
}

Received: January 5, 2019

Accepted: January 15, 2019 Online Published: January 20, 2019

doi:10.5430/ijelt.v6n1p36

URL: https://doi.org/10.5430/ijelt.v6n1p36

\begin{abstract}
Over the past few years, the Persian and English translations of Quran have been studied from different standpoints Throughout the centuries, Muslim and non-Muslim translators have been very concerned to convey the meaning of the Quran into languages other than Arabic. The holy Quran is a divine book and its translation into other languages must be done meticulously. In this regard, Persian and English translation of one of the surahs of this magnificent book was selected to be compared. the present study has gone through the investigation of the Persian translation of one of the surahs of this holy book "Yasin" by Dr. Elahi Ghomshei (1361) and its English translation by three famous translators Yusuf Ali (2000), Pickthall (1930) and Sarwar (2011) to see discrepancies. Also, this study tries to find out the unit of translation and classify different kinds of Vinay and Darbelnet's procedures used by the English translators.
\end{abstract}

Keywords: Quran translation, Vinay and Darbelnet, Yasin, unit of translation

\section{Introduction}

Aiming at guiding mankind into the right path, Holy Quran like other Religious texts has a very significant role in the life of man. Now, the question is how Quran's universal message should be conveyed to the people. The answer is translation. Huge number of Muslims read the English translations of this Holy Book. So it seems necessary to pay due attention to the way these translations are done in different languages especially English. It's the translators' duty to try their bests in order to convey the same meaning into the target languages. In other words, the readers have no choice but to rely on a given translator's faithful rendition.

Different Shiite scholars and clergymen translated this holy book into Persian which is now widespread in Iran and English has also been widespread throughout the world. Due to the critical need for an accurate and clear translation, academic research must be carried out in this domain. Therefore, as a sample, the present study has gone through the investigation of the Persian translation of one of the surahs of this holy book "Yasin" by "Dr. Elahi Ghomshei" and its English translation by three famous translators "Yusuf Ali", "Pickthall" and "Sarwar" to see discrepancies. Also, this study tries to find out the unit of translation and classify different kinds of Vinay and Darbelnet's procedures used by the English translators.

\section{Review of the Literature}

Over the past, the Persian and English translations of Quran have been studied from different standpoints. In this regard, the following studies are worth mentioning: Zolfaqari (2006) studies the reflection of the Quran in Persian proverbs. He reveals the reflection of signs in Persian proverbs in one of the underlying forms: 1) application of the original sign, 2) application of the content of sign, 3) using the words compositions, terms or Quranic interpretation or a part of the sign, 4) allusion of Quranic stories. His study shows that in every 3000 unrepeated published Persian proverbs, the direct effect of about 900 signs of Quran on 3 percent of these proverbs is clear, and that Most of the 
effective signs on proverbs are among the famous signs or in the 30th part of Qur'an.

Muhammed (2007) concentrates on the errors of the translators in rendering the euphemistic expressions in the Quran. His aim in the study is to expose those translators who sacrifice euphemism at the expense of the original meaning and to reveal to what extent these wrong translations affect the understanding of the meaning. He concludes those who mention the euphemism followed by a paraphrase are the best translators as make it easy for the target receivers to understand the intended meaning.

Abdelwali (2007) examines the challenges that Quranic translators encounter at the lexical, structural /stylistic, and rhetorical levels. His study of existing English versions of the Quran shows that the communication of the message without considering the idiosyncrasies and prototypical features of the Quranic discourse is most translators' aim. He concludes that the versatility of Quranic lexemes and styles were not seen in most of the English versions of the Quran.

Elhindi (2008) in his paper categorized and explained the impoertance of metaphors in the Quran and proposed a cognitive approach regarding Lakoff and Johnson principles of the conceptual metaphor theory as a framework. His study focuses on spatial and temporal Quranic metaphors and investigates how they are used to help enhance the interpretation of specific concepts. Furthermore, he addressed the difficulty of translating Arabic metaphors into English and also shows how some of the English translations of metaphors fail to render some of the subtle meanings in the Arabic version.

Roozegar (2012) in her thesis investigated the collocations of Quran and their translations into English and compared 7 English translations with its Persian counterpart and concluded that literal translation was the most frequent method applied by the translators.

Farahani (2013) in his thesis discussed the methods that Quranic names were translated into English and the difficulty the translators faced in rendering these names. He studied three English translations and investigated the strategies adopted by the translators to find out the consistency in rendering these divine names.

Being one of the fundamental concepts always argued about in the realm of translation, the unit of translation (UT) has been given various definitions by different theorists. Shuttleworth and Cowie (1997) define it as: "a term used to refer to the linguistic level at which ST is recodified in TL" (p. 192). Barkhudarov (1993) defines a UT as "the smallest unit of SL which has an equivalent in TL" (as cited in Shuttleworth and Cowie, 1997, p. 192).

Phonemes, morphemes, words, phrases, sentences and entire texts are probable units of translation for him. What determines the appropriate UT, is the wording at a given point in ST. In Koller terms (1979/1992), while closeness of SL and TL involves smaller UTs, translating from a SL which is not that much related to TL will usually result in choosing larger units.

Vinay and Darbelnet (1995) totally draw on the concept of word as a basis for UT. They argue that what should be identified and distinguished as a unit for a translator, who's translating thoughts and concepts, is a unit of thought. Vinay and Darbelnet consider three following terms as being equivalent: "unit of thought", "lexicological unit" and "unit of translation". What they suggest as a definition for UT is" "the smallest segment of the utterance whose signs are linked in such a way that they should not be translated literally"(as cited in Hatim and Munday, 2004, p. 138). (Estaki, 2010)

\section{Methodology}

Major examples of linguistic theories of translation include Vinay and Darbelnet's, inspired by Saussurean linguistics, Catford's, influenced by an early version of Halliday's systemic functional linguistics.

Having identified the linguistic concepts that they consider relevant to translation, Vinay and Darbelnet (1995: 19) turn their attention to the work of translators ... the units they work with, the different planes of language at which these units operate, and finally, the methods which allow the transfer from one language to another (emphasis original).

They point out that "the word on its own is unsuitable for consideration as the basis for a unit of translation" (1995: 20). This is because the word is rarely the unit that signifies, and because meaning, which is what translators are concerned with, is not tied to any formal unit at all. Units of translation are, rather, "lexicological units within which lexical elements are grouped together to form a single element of thought" Vinay and Darbelnet (1995: 21). There follows a long list of types of units (pp. 22-27), a discourse on the three planes of external stylistics, which are the lexicon, the syntactic structures, and the message (pp. 27-30). Compare the differences between English and French 
they identify two translation techniques that somewhat resemble the literal and free methods (Vinay and Darbelnet in Venuti (2004) p.128). Direct (literal) translation discusses three possible strategies:

1) Literal translation or word-for-word

Vinay and Darbelnet say this translation method is only to be used under certain circumstances, i.e. translating word for word in a way that does not alter the meaning is considered an acceptable use of literal translation by the two scholars.

2) Calque, where the SL expression by considering its syntax is literally translated into the TL.

3) Borrowing - when discussing a new technical process for which no term exists within the TL, or when maintaining a word from the SL for stylistic effect, and for adding flavor to the target text (TT) the SL word is transferred directly into the TL and maintaining it in the target language.

Oblique (free) translation covers four strategies:

1- Transposition - interchange of parts of speech that don't affect the meaning, i.e. changing word class without changing meaning.

2- Modulation - reversal of point of view (it isn't expensive / it's cheap). Modulation refers to rendering the TT from a different point of view to that of the ST. it is a way to find a degree of naturalness in TT without sacrificing any meaning or accuracy originating from the ST. Modulation at the levels of message along the following lines: (Munday, 2008, p: 88)

- Abstract $<>$ concrete or particular $<>$ general

- Explicative modulation or effect $<>$ cause

- Whole $<>$ part

- Part<>another part

- Reversal of terms

- Negation of opposites

- Active $<>$ passive

- Rethinking of intervals and limits in space and time

- Change of symbol

3- Equivalence - it is something cultural wherein the same meaning conveyed by a different expression, which is most useful for proverbs and idioms

4- Adaptation - cultural references may need to be altered to become relevant (Vinay and Darbelnet in Venuti (2004) pp129-135).

\section{Research Questions}

RQ1: What strategies do the translators employ in rendering Yasin surah in English?

RQ2: What is the unit of translation used by each translator?

\section{Results and Discussion}

Based on Vinay and Darbelnet (1995) framework, the extracted data in the present study were classified according to the categorizations in the Persian text and the three English renderings. Then, the strategies applied by the three translators in each case were explored thoroughly.

In doing this research, the researcher selected three English translations of the Holy Quran in order to compare and contrast them with the Persian translation text done by "Elahi-qomshei" (). These three translations were done by Yusuf Ali (2000), Sarwar (2011), and Pickthall (1930).

\section{S: I swear by Yasin (1)}

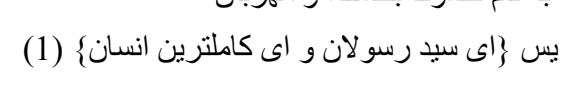


Y: YaSin. (1)

P: YaSin. (1)

As it is clear all the three translators used borrowing for the translation of this verse.

كه به راهى راست فرستاده شدى (4)

S: and that you follow the right path (4)

Y: On a Straight Way (4)

P: On a straight path (4)

As we can see in the Persian translation of this verse the translators used passive tense while in its English equivalents all the three translators used active voice which according to Vinay and Darbelnet the translators used modulation in this verse.

P: A revelation of the Mighty, the Merciful (5)

$$
\text { (5) قاين قران تو كتابى است كه از جانب خداى مقتنر مهربان نازل شده است (5) }
$$

In this verse we have change of parts of speech in the Persian we have a verb which is rendered as a noun in English; therefore, we have transposition.

تا قومى كه بدر انثان به كتب آسمانى يبيشين بيم داده و (و عظ و اندرز) شدند تو هم خود آنها را (به اين قران) بيم دهى (و از قهر حق بترسانى ) كه

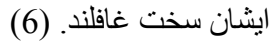

S: so that you may warn a people who are unaware because their fathers were not warned. (6)

Y: In order that thou mayest admonish a people, whose fathers had received no admonition, and who therefore remain heedless (of the Signs of Allah.) (6)

P: That thou mayst warn a folk whose fathers were not warned, so they are heedless. (6)

If one compares the Persian translation with its three English translations, then he might find out that they are not equal in terms of meaning and it can be said that they have semantic difference.

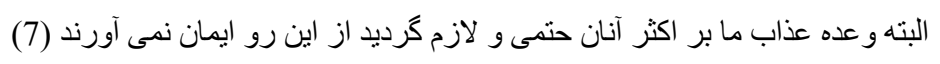

S: (I swear) that most of them are doomed to be punished. They have no faith. (7)

In this verse the Persian translator used active to convey the meaning while the English translator used passive voice; thus, we have modulation here.

ما هم بر كردن آنها تازنخ زنجير هاى عذاب نهاديم در حالى كه \}از جهل و عناد مانند شنر\{ سربلند كرده و جشم بر بسته اند. (8) (8)

S: We have enchained their necks up to their chins. Thus, they cannot bend their heads (to find their way) (8)

Y: We have put yokes round their necks right up to their chins, so that their heads are forced up (and they cannot see) (8)

P: Lo! We have put on their necks carcans reaching unto the chins, so that they are made stiff-necked. (8)

As it can be considered these English translations have semantic difference with their Persian counterpart.

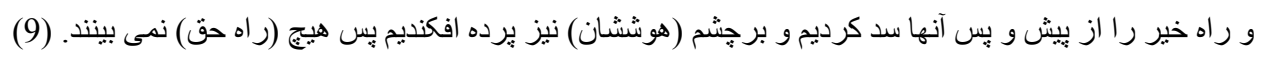

S: We have set-up a barrier in front of and behind them and have made them blind. Thus, they cannot see. (9)

Y: And We have put a bar in front of them and a bar behind them, and further, We have covered them up; so that they cannot see. (9)

P: And We have set a bar before them and a bar behind them, and (thus) have covered them so that they see not. (9)

In the Persian rendering the translator mentioned the part of the body which is particular while in the three translations the translators used the whole body (general) as a reference so we can say that they used modulation.

$$
\text { و نو آنها را بترسانى يا نترسانى يكسان است \} جون دانسته با حق عناد مى ورزند \{ هركز ايمان نمى آورند (10) }
$$

Y: The same is it to them whether thou admonish them or thou do not admonish them: they will not believe. (10)

P: Whether thou warn them or thou warn them not, it is alike for them, for they believe not. (10) 
If one compares and contrasts the Persian and English translations, he will soon understand that in English they used literal translation to convey the same meaning.

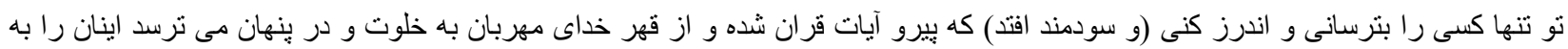

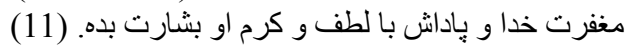

S: You should only warn those who follow the Quran and have fear of the Beneficent God without seeing Him. Give them the glad news of their receiving forgiveness and an honorable reward (from God). (11)

Y: Thou canst but admonish such a one as follows the Message and fears the (Lord) Most Gracious, unseen: give such a one, therefore, good tidings, of Forgiveness and a Reward most generous. (11)

P: Thou warnest only him who followeth the Reminder and feareth the Beneficent in secret. To him bear tidings of forgiveness and a rich reward. (11)

In Sarwar translation we have وريب: in Persian which is a noun but in English we have follow which is a verb so here we have modulation. In Persian we have نآرق تاياً but in English we have Quran in which the particular translated into a general term Quran so again in this part also we have modulation.

In Yusuf Ali translation we have difference of meaning in comparison to its Persian translation.

In Pickthall we have the literal translation of the Persian counterpart.

ما مردكان ا باز زنده مى كردانيم و كردار كذشته و آثار وجودى آينده شان همه شان را ثبت خو اهيم كرد و در لوح محفوظ و روشن خدا (يا قلب امام

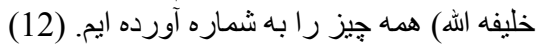

S: It is We who bring the dead to life and records the deeds of human beings and their consequences (of continual effects). We keep everything recorded in an illustrious Book. (12)

Y: Verily We shall give life to the dead, and We record that which they send before and that which they leave behind, and of all things have We taken account in a clear Book (of evidence). (12)

P: Lo! We it is Who bring the dead to life. We record that which they send before (them, and their footprints. And all things We have kept in a clear Register. (12)

As it can be seen in all English translations we have literal translation.

اهل قريه به رسو لان كفتتد: شما جز اينكه مانند ما مردم بشرى هستيد مقام ديكرى نداريد و هركز خداى ردمان ردمان جيزى را فرو نفرستاده است مكر

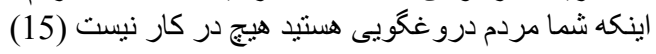

S: The people said, "You are mere mortals like us and the Beneficent God has sent nothing. You are only liars." (15)

Y: The (people) said: "Ye are only men like ourselves; and ((Allah)) Most Gracious sends no sort of revelation: ye do nothing but lie." (15)

P: They said: Ye are but mortals like unto us. The Beneficent hath naught revealed. Ye do but lie! (15)

In Sarwar translation we have people and in Persian we have هل قريه in which the translator used the general term for rendering a particular word so here we have modulation, in the middle part we have mortals for بشر wherein we have modulation for using an abstract item instead of the concrete one and again in the last part of the verse he used modulation for having the negation of opposites.

In Yusuf Ali translation we have revelation for جيز in which the translator brought a particular word for a general word and used modulation in this verse.

In Pickthall like in Sarwar translation the translator used mortals for the word بشر and here also the translator used modulation in the translation and at the end also used negation of opposites.

$$
\text { رسو لان باز كفتند: خداى ما مى داند كه محققا ما فرستاده او بسوى شما هنتيم (16) }
$$

S: They said, "Our Lord knows that We are Messengers (16)

Y: They said: "Our Lord doth know that we have been sent on a mission to you: (16)

P: They answered: Our Lord knoweth that we are indeed sent unto you, (16) In the three translations all the translators used literal translation.

$$
\text { و بر ما جز آنكه واضح ابلاغ رسالت كنيم هيج تكليفى نيست (17) }
$$

S: have been sent to you. Our only duty is to preach clearly to you (17) 
Y: "And our duty is only to proclaim the clear Message." (17)

P: And our duty is but plain conveyance (of the message). (17)

In all the three translations we have negation of opposites which is a modulation procedure.

باز منكر ان كفتند كه ما وجود شما را به فال بد كرفتيم؛ اكر (از اين دعوى) دست برنداريد، البته سنكسارتان خواهيم كرد و از ما به شما رنج و

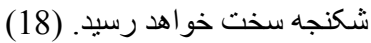

S: The people said, "We have ill omens about you. If you will not desist, we shall stone you and make you suffer a painful torment" (18)

Y: The (people) said: "for us, we augur an evil omen from you: if ye desist not, we will certainly stone you. And a grievous punishment indeed will be inflicted on you by us." (18)

P: (The people of the city) said: We augur ill of you. If ye desist not, we shall surely stone you, and grievous torture will befall you at our hands. (18)

In Sarwar translation we have people for ناركن so the translator used the general word for theparticular item and in the last part also used reversal of terms for rendering the same meaning; therefore, the translator used modulation in both parts.

Yusuf Ali and Pickthall used literal translation in this verse.

$$
\text { از آنها كه هيج اجر و مزد رسالتى از شما نمى خو اهند و خود \} به راه حق\{ هدايت يافته اند بيروى كنيد(21) }
$$

S: Follow those who do not ask you for any reward and who are rightly guided. (21)

Y: "Obey those who ask no reward of you (for themselves), and who have themselves received Guidance. (21)

P: Follow those who ask of you no fee, and who are rightly guided. (21)

If we compare and contrast the Persian translation with its three English translations, we can understand that they have difference in meaning.

$$
\text { و جر ا بايد من خداى آفريننده خود را نبرستم در صورتى كه باز كثت شما (و همه خلائقُ بسوى اوست (22) }
$$

S: "Why should I not worship God who has created me? To him you will all return (22)

Y: "It would not be reasonable in me if I did not serve Him Who created me, and to Whom ye shall (all) be brought back. (22)

In the first translation we have negation of opposites so we have modulation and in the latter we have transposition wherein a noun transformed into the verb then we have transposition.

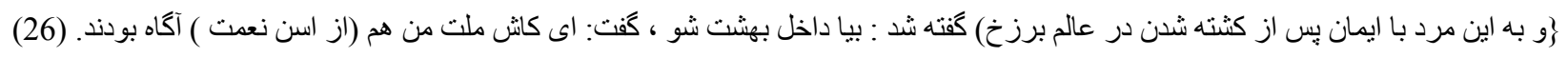

S: (Having been murdered by the disbelievers) he was told to enter paradise (26)

و ما بِ از او (يعنى حبيب) بر قومش هيج لشكرى از آسمان نفرستاديم ( تابر ايمان مجبورشان كنند) و هيج اين كار (با ملتى) نكرده ايم و نخو اهيم كرد. (28)

P: We sent not down against his people after him a host from heaven, nor do We ever send. (28)

In both of the above translations the translators used the literal translation.

$$
\text { كه خدا جُونه در حق من مغفرت فرمود و مر امورد لطف و كرم قرار داد (27) }
$$

S: (wherein he said), "Would that people knew how my Lord has granted me forgiveness and honor" (27)

P: With what (munificence) my Lord hath pardoned me and made me of the honored ones! (27) In the first translation the translator used literal translation but in the latter one we have transposition wherein a verb used for a noun.

$$
\text { نبود عقو بتشان جز يكى صيحه عذاب آسمانى كه به ناكاه همه هلاك شدند (29) }
$$

S: It was only a single blast which made them extinct. (29)

P: It was but one Shout, and lo! they were extinct. (29)

In both of the above translations the translators used negation of opposites which is part of a modulation procedure.

$$
\text { واى بر حال اين بندكان \}كمر اه لجوج\{ كه هيج رسولى براى هدايت آنها نيامد جز آنكه او را به تمسخر و استهز ا كرفتند (30) }
$$


S: Woe to human beings! Whenever a Messenger came to them, they mocked him (30)

Y: Ah! Alas for (My) Servants! There comes not an apostle to them but they mock him! (30)

P: Ah, the anguish for the bondmen! Never came there unto them a messenger but they did mock him! (30)

In the first translation we have negation of opposites which is a part of modulation procedure. In the second and third translation we have literal translation.

$$
\text { و هيجِكس \}از كذنته و آينده در عالم\{ نيست جز آنكه همه نزد ما حاضر آورده مى شوند. (32) }
$$

S: They will all be brought into Our presence together. (32)

Y: But each one of them all - will be brought before Us (for judgment). (32)

P: But all, without exception, will be brought before Us. (32)

As it is clear all the three translators used negation of opposites to convey the same meaning into English; therefore, they used modulation in this verse.

$$
\text { و يكى برهان براى آنها (بر اينكه ما مردكان را زنده مى كنيم) آن است كه زمين مرده را (به بار ان رحمت\{ زنده كرده و از دانه هايى كه قوت و }
$$

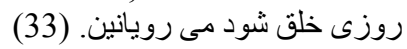

Y: A Sign for them is the earth that is dead: We do give it life, and produce grain therefrom, of which ye do eat. (33)

P: A token unto them is the dead earth. We revive it, and We bring forth from it grain so that they eat thereof; (33)

In both of the above translations the translators used the verb eat for يزور و تنوق which is a noun so we can say that they used transposition in their translations.

$$
\text { و در زمين باغ ها از نخل خرماو انكور قرار داديم و در آن جشمه هاى آب جارى ساختيم (34) }
$$

S: produced therein grains from which they eat and established therein gardens of palms trees and vineyards and have made streams flow therein (34)

Y: And We produce therein orchard with date-palms and vines, and We cause springs to gush forth therein: (34)

P: And We have placed therein gardens of the date-palm and grapes, and We have caused prings of water to gush forth therein, (34)

From the above translations it is clear that all the three translators used literal translations for conveying the same meaning in English.

$$
\begin{aligned}
& \text { تا مردم از ميوه هاى آن باغ ها تناول كنند و از انواع غذاهايى كه (از اين ميوه ها و نباتات) به دست خود عمل مى آورند نيز تغذيه نمايند. آيا نبايد }
\end{aligned}
$$

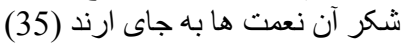

Y: That they may enjoy the fruits of this (artistry): It was not their hands that made this: will they not then give thanks? (35)

P: That they may eat of the fruit thereof, and their hands made it not. Will they not, then, give thanks? (35)

According to the bold face type of the above translations it is evident that they have difference in meaning with their Persian equivalent.

$$
\text { و بر هان ديكر براى خلق (در اثبات قدرت حق) وجود شب است كه ما جون برده روز را از آن بركيريم ناكهان همه آنان (و همه قيز) در تاريكى }
$$

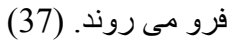

S: Of the signs for them is how We separated the day from the night and thus they remained in darkness; (37)

The translator changed the symbol in the translation for rendering the same meaning in English so we can say that he used modulation in this process.

$$
\text { نه \}در كردش منظم عالم\{ خورشيد را شايد كه به ماه فرا رسد و نه شب بر روز سبقت كيرد و هريك بر مدار معينى \}در اين درياى بى بايان\{ }
$$

S: how the sun is not supposed to catch-up with the moon, nor is the night to precede the day. All of them are to float in a certain orbit; (40)

Y: It is not permitted to the Sun to catch up the Moon, nor can the Night outstrip the Day: Each (just) swims along in (its own) orbit (according to Law). (40)

P: It is not for the sun to overtake the moon, nor doth the night outstrips the day. They float each in an orbit. (40)

In the first and the third translations, the translator used literal translation for rendering the same meaning in English. 
In the second translation the active voice translated into the passive construction so we can say that the translator used modulation in this verse.

$$
\text { و بر هان ديكر بر ای آنها آنكه ما فرزندان آنان (يعنى بشر) را در كثنى بربار سوار كردانيديم. (41) }
$$

P: And a token unto them is that We bear their offspring in the laden ship, (41)

In the Persian we have the general term wherein in English the translator used the particular word for rendering the same meaning; thus, he used modulation in this verse.

و نيز بر اى آنان به مانتد كثنى جيزى كه بر آن سو ار شوند خلق كرديم (شايد ات.مبيل و ترن و طياره مقصود بانثد). (42)

S: and created for them similar things to ride. (42)

P: And have created for them of the like thereof whereon they ride. (42)

In the above translation the translators used literal translation in rendering the same meaning in English.

$$
\text { و بر اين مردم \}غافل\{ هيج از آيات الهى نبايد جز آنكه از آن اعراض كنند. (46) }
$$

S: and whenever a revelation out of their Lord's revelations comes to them, they ignore it (46)

P: Never came a token of the tokens of their Lord to them, but they did turn away from it! (46)

The translators used negation of opposites in rendering the verse in translation so the translators used modulation in this process.

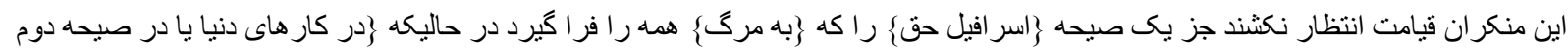

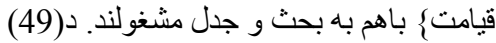

P: They await but one Shout, which will surprise them while they are disputing. (49)

In this verse the translator used modulation because he used negation of opposites.

$$
\text { و \} جون بار دوم\{ در صور دميده شود به ناكاه همه از قير ها به سوى خداى خود به سرعت مى شتابند. (51) }
$$

S: When the trumpet is sounded, they will be driven out of their grave into the presence of their Lord. (51)

The translator changed symbol in this verse, i.e. modulation.

$$
\text { و كويند: اى واى بر ما، كه ما را از خو ابحاهمان بر انكيخت؟ اين همان وعده خداى مهربان است و رسو لان همه راست كفتند. (52) }
$$

S: They will say, "Woe to us! Who has raised us up from our graves? This is what the Beneficent God has promised. The Messengers have also spoke the truth" (52)

P: Crying: Woe upon us! Who hath raised us from our place of sleep? This is that which the Beneficent did promise, and the messengers spoke truth. (52)

The blood face type word in the Persian is a noun which in English translations it changed into a verb so transposition is used in this verse.

$$
\text { و آن جز يك صيحه \}و يك لحظه بيش\{ نباثد كه ناكاه تمام خلايق محشر به ييشحاه ما حاضر آورده خو اهند شد. (53) }
$$

S: Only after a single blast of sound, they will all be brought into Our presence (53)

P: It is but one Shout, and behold them brought together before Us! (53)

The first translator used literal translation while the second translator used modulation as he used negation of opposites.

$$
\text { بس در آن روز كمترين ظلمى به هيجِكس نشود و جز آنجه عمل كرده ايد ابداً جز ايى نخو اهيد يافت. (54) }
$$

S: No soul will be in the least bit wronged on that Day and no one will receive any recompense other than what he deserves for his deeds. (54)

Y: Then, on that Day, not a soul will be wronged in the least, and ye shall but be repaid the meeds of your past Deeds. (54)

P: This day no soul is wronged in aught; nor are ye requited aught save what ye used to do. (54)

In the Persian the bold face type words are verb which in the first translation they are translated as a noun in English, so the translator used transposition and modulation because the passive voice was translated into the active voice.

In the second translation like the first one we have modulation as the English translator used active while the Persian used passive. 
In the last English translation, we have negation of opposites and of course modulation.

$$
\text { خطاب آيد آى آدم ز ادكان، آيا به شما سفارش ننموده ام كه شيطان را نبرستيد ، زير ا روشن است كه او دشمن بزرگ شماست. (60) }
$$

Y: "Did I not enjoin on you, O ye Children of Adam, that ye should not worship Satan; for that he was to you an enemy avowed? (60)

P: Did I not charge you, O ye sons of Adam, that ye worship not the devil - Lo! he is your open foe! (60)

$$
\text { و مر ا برسنش كنيد، كه اين ر اه مستقيم \}سعادت ابدى\{ است. (61) }
$$

Y: "And that ye should worship Me, (for that) this was the Straight Way? (61)

P: But that ye worship Me? That was the right path. (61)

In the two verses mentioned above the Persian and English translations are equal to each other and the translators used literal translation.

$$
\text { و همانا خلق بسيارى از شما نوع بشر را \}اين ديو جبه كمر اهى كثيد، آيا عقل و فكرت كار نمى بستيد \}تا از مكر و فريبش بير هيزيد\{. (62) }
$$

P: Yet he hath led astray of you a great multitude. Had ye then no sense? (62)

The bold face type is an expression in Persian and the translator also used an equivalent expression in English so we can say that the translator used equivalence in this verse.

$$
\text { و اكر بخو اهيم همانجا صورت آنهار را مسخ كنيم \}تا به شكل سكان و بوزينكان شوند\{ كه نه \}از آن صورت يا از آن جائ يتو انند كنشت و نه جبه }
$$

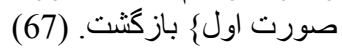

P: And had We willed, we verily could have fixed them in their place, making them powerless to go forward or turn back. (67)

As one compares Persian and English translation of this verse he can easily find out that they are difference in meaning.

$$
\text { تا هر كه رازنده دل است \}به آياتش بند دهد و ازخداو قيامت\{ بترساند و بر كافران \}نيز به اتمام حجت\{ و عده ععذاب حتم و لازم كردد. (70) }
$$

P: To warn whosoever liveth, and that the word may be fulfilled against the disbelievers. (70)

The bold word in the Persian is a noun while in English a verb is used instead; therefore, the translator used transposition here.

$$
\text { آيا كافر ان نديدند كه بر آنها به دست (قدرت\{ خود از جمله آفريدكان جهاريايانى خلقت كرديم تا مالك آنها شوند.(71) }
$$

S: Have they not seen what We have created from the labor of Our own hands? We have given them cattle (71)

Y: See they not that it is We Who have created for them - among the things which Our hands have fashioned - cattle, which are under their dominion? (71)

In the first translation we have the general term but in English we have the particular word as a result modulation was used here.

In the second translation an expression is replaced by its equivalent expression in English so here the translator used equivalence in this verse.

$$
\text { و آن حيو انات \}با عظمت و قوت\{ را مطيع و رام آنها ساختيم كه هم بر آنها سوار شوندو هم از آنها غذا تناول كنند. (72) }
$$

Y: And that We have subjected them to their (use)? of them some do carry them and some they eat: (72)

Here the English translator used reversal of terms to render the same meaning in English, i.e., modulation was used here.

و براى آنها در آن حيو انات منافع \} بسيارى از بوست و يشم و كرك و غيره\{ و آثاميدنى هاى فراوان \}(ز شير و ماست و روغن و غيره\{ هست، آيا

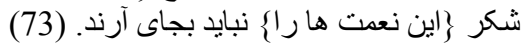

S: From cattle they get milk and other benefits. Will they not then give thanks? (73)

Y: And they have (other) profits from them (besides), and they get (milk) to drink. Will they not then be grateful? (73)

In the first translation a general word in Persian is translated into a particular word in English and in the latter the passive construction in Persian changed into the active construction; thus, in both parts we have modulation.

هركز آن خدايان كمترين نصرنى به آنها نتو انند كرد و خود اين مشركان معبودانشان را سياهى حاضر خدمت هستند كه همكى را إدر فيامت در آتش دوزخُ حاضر آرند. (75) - (75) 
Y: They have not the power to help them: but they will be brought up (before Our Judgment-seat) as a troop (to be condemned). (75)

$\mathrm{P}$ : It is not in their power to help them; but they (the worshippers) are unto them a host in arms. (75)

In the first translation the identified part is an effect while in its English counterpart the cause is used instead, the same is true for the second translation so in both parts modulation was used by the translators.

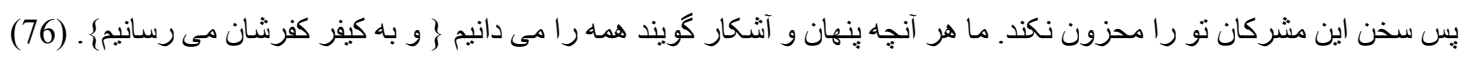

S: Muhammad, let not their words annoy you. We certainly know whatever they conceal or reveal. (76)

P: So let not their speech grieve thee (O Muhammad). Lo! We know what they conceal and what proclaim. (76)

In the above translations the translators used literal translation to convey the meaning.

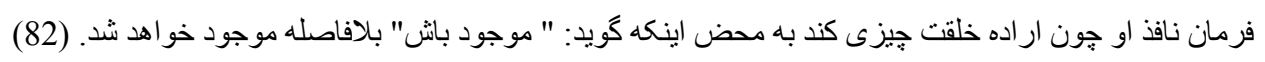

S: Whenever He decides to create something He has only to say, "Exist," and it comes into existence. (82)

In the Persian the bold face word is a noun but in English a verb is used instead, so transposition is used in this verse.

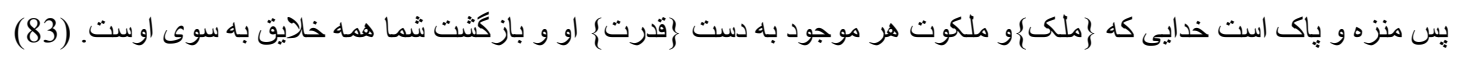

S: All glory belongs to the One in whose hands is the control of all things. To Him you will all return. (83)

Y: So glory to Him in Whose hands is the dominion of all things: and to Him will ye be all brought back. (83)

Both used literal translation to convey their meaning into English.

By comparing Persian translation of the Holy Quran and its three English counterparts and according to the data gathered above it can be understood that in: Sarwar translation: the translator mostly used modulation then benefited from literal translation and transposition and borrowing while rendering Yasin into English.

Yusuf Ali Translation: the translator mostly used modulation and literal translation and then transposition and borrowing and equivalence.

Pickthall translation: the translator benefited more from literal translation and modulation then from transposition, borrowing and equivalence.

In verses 6,8 and 21 there exists discrepancies and difference in meaning between Persian and its three English translations.

In verse 11 there is a discrepancy between Yusuf Ali translation and its Persian counterpart.

In verse 35 the Persian translation was different from Pickthall and Yusuf Ali translation.

In verse 67 there exists a discrepancy between Pickthall and its Persian rendering.

\section{Conclusion}

Therefore, it seems that the selected translators regard modulation and literal translation as the best choices for the translation of Yasin surah. All three translators were so faithful to the meaning of Quran and they consider meaning of each verse as their unit of translation and they were so meticulous on choosing appropriate words for their translations. Furthermore, it can be said that their unit of translation was small which is suitable for translating an expressive and authoritative text such as Quran.

\section{References}

Abdelwali, M. (2007). The Loss in the translation of the Qur'an. Translation Journal, 11(2). Retrieved from http://accurapid.com/journal/40quran.htm

Barkhudarov, L. (1993). The problem of the unit of translation. In P. Zelateva (Ed.), Translation as social action: Russian and Bulgarian perspectives (pp. 39-46). London and New York: Routledge.

Benjamins Translation Library 11. Amsterdam and Philadelphia: John Benjamins Publishing Company.

Elhindi, Y. (2008). 'Metaphors in the Quran: Categories and significance'. Paper presented at the sixth international conference on new directions in the humanities. Fatih University. Retrieved 15-18 July 2008 from http://h08.cgpublisher.com/proposals/381/index_html 
Esteki, A. (2010) What Is to Be Considered as A Unit of Translation? Retrieved from http://www.translationdirectory.com/articles/article2124.php

Farahani, M. (2013). A corpus-based study on English translations of the divine name in the Holy Quran. International Journal of Linguistics, 5(1), 128-142. http://dx.doi.org/10.5296/ijl.v5i1.3301

Hatim, B., \& J. Munday. (2004). Translation: An advanced resource book. London/New York: Routledge. https://doi.org/10.4324/9780203501887

Koller, Werner. (1992). Einführung in die Übersetzungswissenschaft (2nd ed.). Heidelberg: Quelle \& Meyer.

Muhammed, G. A. (2007). Errors in English translations of euphemism in the Holy Qur'an. Qur'anic Studies. Retrieved from http://www.quranicstudies.com/articles/language-of-the-quran

Munday, Jeremy. (2008). Introducing translation studies. Theories and applications. London and New York: Routledge.

Pickthall, M. M. (1930). The Meaning of the Glorious Qur'an. Retrieved from http://www.khayma.com/librarians/call2islaam/quran/pickthall/

Roozegar, A. (2012). Strategies applied in translating Quranic lexical collocations (A corpus-based study on chapters 2,3,4,6 \& 7). Unpublished M.A. thesis, Islamic Azad University of Tehran.

Sarwar, M. (2011). The Holy Qur'an: The Arabic Text and English Translation. Retrieved from http://www.clay.smith.name/Parallel_Quran.htm.

Shuttleworth, M., \& Cowie, M. (1997). Dictionary of translation studies. London and New York: Routledge. ISBN 13: 978-1900650-03-8.

Venuti, L. (2004). The translation studies reader. London \& New York: Routledge.

Vinay, Jean-Paul \& Jean Darbelnet. (1995). Comparative Stylistics of French and English: A Methodology for Translation. Translated and edited by Juan C. Sager and M.-J. Hamel. https://doi.org/10.1075/btl.11

Yusuf Ali, A. (2000). The Holy Qur'an: Text, Translation and Commentary. Wordsworth edition limited.

Zolfaqari, H. (2006). The Reflection of Holy Quran in Persian Proverbs. Journal of the Iranian Association of Arabic Language and Literature, 2(5), 109-136.

$$
\text { الهى قمشه ای، ح. (1361). قران كريم. انتشار ات امير كبير. تهران }
$$

